Ирина Стародубровская

\title{
КРИЗИС ТРАДИЦИОННОЙ СЕВЕРОКАВКАЗСКОЙ СЕМЬИ В ПОСТСОВЕТСКИЙ ПЕРИОД И ЕГО СОЦИАЛЬНЫЕ ПОСЛЕДСТВИЯ
}

Северный Кавказ рассматривается как своеобразный «заповедник» семейного традиционализма, т.е. семейных отношений, основанных на жестких поколенческих и гендерных иерархиях, существенной роли «большой» семьи (рода), регулярном применении домашнего насилия. Однако исследования показывают, что в действительности традиционная модель северокавказской семьи находится в кризисе. Этот тезис обосновывается с использованием результатов как количественного, так и качественного социологического анализа. Качественные исследования, проведенные автором в различных регионах Северного Кавказа в 2014-2018 гг., позволяют выделить факторы и последствия ослабления поколенческих и гендерных иерархий, выделения семьи из рода и местного сообщества. Количественное исследование, проведенное с применением онлайн-методики в 2017 г., подтверждает разрушение поколенческих иерархий, инструментом которого служит радикальный ислам, но при этом демонстрирует консервативный поворот в гендерных вопросах. Этот поворот сопровождается усилением разрыва между гендерными ценностями мужчин и женщин от старшего к молодому поколению (величина этого разрыва между мужчинами и женщинами отличается также от региона к региону), что может послужить основой кризиса в данной сфере в будущем. Показано противоречивое влияние на семейную сферу «нетрадиционного» ислама, который, с одной стороны, закрепляет имеющиеся гендерные иерархии внутри семьи, а с другой стороны, усиливает представление о персональной ответственности в противовес ответственности рода. Социальные последствия кризиса традиционной семьи связаны в первую очередь с невозможностью контроля старших над молодым

Ирина Викторовна Стародубровская - к.э.н., руководитель научного направления «Политическая экономия и региональное развитие», Институт экономической политики им. Е. Т. Гайдара, Москва, Россия. Электронная почта: irinavstar@gmail.com 
поколением и неэффективностью апелляции к их авторитету в ситуациях не соответствующих нормам поведения северокавказской молодежи в других российских регионах или исламской радикализации. На основании полевых исследований показана неадекватность подходов к молодежной политике, основанных на представлении о незыблемости традиционных форм семейной организации в северокавказских сообществах.

Ключевые слова: традиционная семья, поколенческие и гендерные иерархии, брачные стратегии, консервативные гендерные ценности, ислам

DOI: 10.17323/727-0634-2019-17-1-39-56

Общим местом стало представление о традиционности северокавказской семьи, сохраняющей старинные обычаи: авторитарный отец-добытчик, занимающаяся ведением хозяйства и воспитанием подрастающего поколения жена, послушные дети, не смеющие возразить старшим. Это представление, получившее широкое распространение, обнаруживается и в научных работах. Так, Ирина Молодикова и Алан Уотт (Molodikova, Watt 2014:92, 106), анализируя условия социализации подрастающего поколения на Кавказе, отмечают, что «семейные отношения до сих пор базируются на превосходстве мужчин, и механизм социального контроля традиционно основывается на доминировании старшего поколения над более молодыми членами семьи», считая, что «социальная система до сих пор цементируется консервативными семейными ценностями и < .. > патриархальными структурами» и признавая в ней лишь незначительные признаки модернизации. Между тем проведенные полевые исследования демонстрируют, что подобные оценки существенно преувеличивают архаичность сложившейся модели семейных отношений. Нельзя сказать, что традиционная кавказская семья полностью разрушена, однако она, безусловно, переживает серьезный кризис. Этот кризис по-разному проявляется в различных северокавказских республиках, но его последствия видны повсеместно.

Настоящее исследование основано на изучении 35 сельских и городских сообществ в пяти республиках Северного Кавказа: Дагестане, Чечне, Ингушетии, Кабардино-Балкарии (КБР), Карачаево-Черкесии (КЧР). Исследование базировалось на качественных методах. Всего за 2014-2018 гг. проведено около 200 индивидуальных и групповых интервью и 20 фокус-групп. Кроме того, включает анализ двух количественных опросов дагестанских мусульман и мусульман Чечни и Ингушетии об их ценностях. Изучаемые сообщества были разными по размерам, неодинаково располагались (равнина, предгорья, горы), имели разную хозяйственную специализацию. Основной акцент в исследовании делался на процессах трансформации поколенческих и гендерных иерархий, на родовых отношений, на роли местного сообщества, влиянии адатов и ислама в системе социальных регуляторов, на жизненных стратегиях молодежи. Основные группы интервьюируемых: руководители муници- 
пальных образований, представители депутатского корпуса, директора и учителя школы, старейшины, имамы (религиозные лидеры), местный бизнес, общественники, религиозная и светская молодежь, в т. ч. старшеклассники, представители диаспор из данных населенных пунктов в городах (если речь шла о сельских населенных пунктах). Большое внимание в настоящей публикации уделено ситуации на Северо-Восточном Кавказе. При этом необходимо отметить, что аналогичные кризисные явления в сфере семейных отношений проявляются и на Северо-Западном Кавказе, хотя там они имеют свою специфику.

\section{Факторы трансформации традиционной модели семьи}

Понятие традиционной семьи полезно обосновать через работы основоположника различения традиционного и современного общества Фердинанда Тенниса, который выделял Gemeinschaft - то, что на русский язык переводится как община или общность, а в дальнейшем стало называться традиционным обществом, и Gesellschaft - общество современного типа. Семья, дом, домохозяйство в первой из этих моделей играют принципиальную роль: «[и]зучая дом, мы изучаем общность, как, изучая органическую клетку, мы изучаем саму жизнь» (Теннис 2002: 43). Основные выделенные Теннисом характеристики Gemeinschaft, представляющие для нас интерес в данном исследовании, сводятся к следующим: наличие жестких возрастных и гендерных иерархий; органическое единство личности и общины, растворение индивидуального в коллективном; семья и род как базовые характеристики общности (любая общественная организация строится на базе семейной организации и воспроизводит ее структуру); стыд и страх как важнейшие регуляторы поведения индивида.

Необходимо отметить, что категория традиционного общества вызвала большую дискуссию в социологической и антропологической литературе, возможности и границы ее использования неоднократно ставились под вопрос (Lewis 1973; Tipps 1973). Исследования на Северном Кавказе показали, что описанная Теннисом модель в целом отражает реалии традиционных отношений в северокавказских сообществах. Традиционная модель семьи (с определенными вариациями) была характерна для северокавказского общества в досоветский период. Это становится понятным, если, например, сравнить описание дореволюционной кавказской семьи в работе Ярославы Смирновой «Семья и семейный быт народов Северного Кавказа» (Смирнова 1983) с характеристиками Gemeinschaft у Тенниса. В советское время произошло некоторое размывание традиционных отношений, однако оно было очаговым и не привело к подрыву базовых основ традиционной семьи. Более того, Энвер Кисриев, например, утверждает применительно к Дагестану, что «в условиях коммунистического режима оказались как бы "возрожденными" базисные признаки традиционного 
дагестанского общества» (Кисриев 2004: 76) даже по сравнению с царскими временами, что не могло не сказаться и на семейных отношениях.

Как показывают результаты проведенных мною исследований, наиболее заметный этап кризиса традиционной семьи начался в постсоветское время, причем его преемственность с советской социальной модернизацией не является линейной. Эта нелинейность связана с тем, что прежние центры модернизации на Северном Кавказе - города - в постсоветский период стали территориями активных миграционных процессов. Причем эта миграция имела два направления: из северокавказских городов в другие регионы уезжало наиболее образованное население, а в города мигрировали люди с сельской периферии. Прежние городские модели жизни были в значительной степени подорваны.

В то же время в постсоветский период кризис традиционных отношений имел собственные источники. Во-первых, к таким источникам относилось развитие рыночных отношений. Авторитет старшинства во многом заменялся авторитетом богатства. Главенствующую роль в социуме стали играть те, кому удалось «выбиться в люди», и часто это оказывались представители диаспор - выходцы из сел, проживающие в городах:

...традиционное единство и порядок в джамаатах ${ }^{1}$ в новых условиях обеспечивалось установлением со стороны богатой семьи с помощью религиозных авторитетов покровительства над остальными жителями родного джамаата. Взамен джамаат обеспечивал своего покровителя голосами на разнообразных выборах, оказывал содействие в случаях, когда возникала необходимость силовой поддержки, защиты его экономических интересов и удержания административных позиций (Кисриев 2004: 129).

В некоторых случаях это вписывалось в логику межродовых отношений. Однако в основном новая стратификация вступала в противоречие с традиционной и способствовала ее подрыву. В рыночных условиях во многом обесценивался опыт старших поколений по формированию жизненных стратегий и организации жизни. Молодые, более гибкие и динамичные, в большей мере владеющие новыми технологиями часто становились более успешными, обретали экономическую самостоятельность. И это способствовало расшатыванию поколенческих иерархий. Необходимость адаптироваться к рыночным условиям влияла и на гендерные отношения. Нередки были ситуации, когда мужчины не справлялись с этой задачей, и основными добытчицами в семье становились женщины - они торговали на рынках, занимались изготовлением ремесленных изделий, работали учителями, врачами (см. напр., Сабанчиева 2016; Павлова 2013).

\footnotetext{
${ }^{1}$ Джамаат в данном случае - традиционная сельская община в Дагестане.
} 
Во-вторых, источником кризиса традиционной семьи в постсоветское время были активно шедшие в ряде северокавказских республик процессы урбанизации. Старшему поколению, привыкшему к сельской жизни и не имеющему необходимых связей, далеко не всегда удавалось адаптироваться к новым условиям, что снижало его авторитет:

Заработать можно было только здесь, они приезжали в Махачкалу, потому что там нечего делать, в горах. Вы же понимаете, что Махачкала, оставшись без промышленного комплекса, тоже превратилась в такое, знаете - кто что урвет. Кто-то урвал, кто-то не урвал, у кого-то хватило знаний, кто-то компенсировал свои незнания силой... подлостью... То есть из всей этой каши огромное количество людей - неудачники, которых оттуда сорвали, с прежнего образа жизни, к этому они не пристали. Эти люди, естественно, у них ничего не получилось <..> им сейчас по 45 , по 50, ихним детям - по 20, по $25<\ldots>$ [у них] на самом деле нет старших как авторитетов (муж., сред. возраст, Дагестан).

Дети первых мигрантов из сельских районов, уже горожане, часто более образованные, чем родители, должны были искать собственные ценности и смыслы в культурно гетерогенной городской среде без опоры на старших. Горизонтальные городские сообщества начинали играть все более важную роль, тесня родственные иерархии.

В-третьих, источником кризиса традиционного семейного уклада стали процессы глобализации. Альтернативные алгоритмы и модели поведения приходили в северокавказский социум как со стороны Европы, так и с Востока. Нормы европейской культуры, нормы арабской культуры - все это стало доступным и разрушало традиционную замкнутость локального социума. Интернет, социальные сети либерализовали отношения между людьми, в том числе между молодежью разного пола, создали альтернативные привычным брачные стратегии. Как видно из исследования Стародубровской и Соколова, это существенно изменило спектр воспринимаемой информации и интересов, стало задавать модели потребительского поведения: «Раньше, если ты видел здоровую девушку..., то ты мог сразу сказать - вот это сельская, приученная к работе. А сейчас они все ложатся спать - Дом-2, Одноклассники, или "ой, замуж вышла новая принцесса английская за этого принца". Вот об этом обсуждают - шляпки, тряпки» (цит. по: Стародубровская, Соколов 2013:55).

В-четвертых, идеологической основой разрушения традиционных отношений во многом являлся фундаменталистский ислам. В первую очередь его «мишенью» стали поколенческие иерархии. Молодые люди рассматривали себя носителями религиозной истины, которая была для них важнее, чем мнение старшего или ориентация на предков. Идея о том, что «если брать отцовское слово и слово Всевышнего, то выше слово Всевышнего» (муж., мол. возраст, Дагестан), фактически ставит под вопрос саму основу традиционной семьи (да и традиционной модели общественных 
отношений в целом), поскольку, по словам Тенниса, «отцовство выступает как наиболее чистое основание идеи господства в рамках общности» (Теннис 2002:20). Характерный для ислама акцент на индивидуальной, а не коллективной ответственности также способствовал эрозии традиционных отношений, становлению индивидуальности в противовес растворению индивида в коллективе.

\section{Характеристика трансформации традиционных семейных отношений: результаты качественного исследования}

Остановимся на основных характеристиках трансформационных процессов, которые выявлены в ходе полевого исследования. Обращает на себя внимание, что семья все больше выделяется из традиционных «коллективностей» - рода и местного сообщества, становится нуклеарной. В подавляющем большинстве сельских сообществ представители либо среднего, либо старшего поколения вспоминают практически одну и ту же модель отношений в прошлом, когда сообщество в целом выступало регулятором поведения молодежи:

Вот я в школе, вот мы в школе учились. Нас учителя, бывало, там так надают нам тумаков. Так я был готов, чтобы меня там убили, лишь бы дома не сообщили. Если родителям скажут, это вообще, меня совсем убьют. Тоже, если узнают только, что учитель мне замечание сделал (муж., сред. возраст, КЧР).

Старший мог потребовать от младшего практически любой услуги, при этом младший не мог отказать, а если старший оставался недоволен, младший подвергался наказанию. Физические наказания, в том числе публичные, применялись практически повсеместно - например, могли выпороть перед всем классом. Страх и стыд выступали универсальными регуляторами поведения: «Ребенок должен чего-то бояться < .. > Чего-то должен бояться. Без страха нет стыда» (муж., стар. возраст, Дагестан). Молодые боялись даже просто пройти мимо годекана - места сбора мужчин в селе.

Подобная модель коллективного регулирования уходит в прошлое. Сейчас семьи стремятся монополизировать право на воспитание детей, причем модели организации семьи в каждом отдельном сообществе могут различаться с точки зрения степени свободы молодого поколения и их права принимать самостоятельные решения, модели гендерных отношений, уровня семейного насилия: «в одном доме совсем европейские какието правила, а здесь - азиатские» (жен., сред. возраст, КЧР). Согласно интервью, окончательной инстанцией для принятия решений становится отец - другие родственники, в том числе старшие, уходят на задний план. Функции главы рода становятся номинальными (участие в организации свадеб, похорон), а сам род теряет свое значение и перестает быть струк- 
турообразующей единицей местного сообщества. Сходит на нет ответственность рода за своих членов. Взаимопомощь сохраняется в основном между близкими родственниками.

Необходимо отметить, что все эти процессы происходят очень неравномерно в различных северокавказских республиках. В Чечне и особенно в Ингушетии, где нет крупных городов и роды (тейпы) до сих пор живут компактно, традиционные отношения разрушаются не столь стремительно. Здесь, как показывают проведенные мною исследования, сохраняется ответственность рода за своих членов (в том числе в рамках кровной мести), коллективное регулирование поведения молодых, более значимы роль старейшин и влияние расширенной семьи. Это серьезно отличается от ситуации в Дагестане (которая также чрезвычайно дифференцирована по разным территориям), где в некоторых местах при вопросе о роли рода (тухума) в их жизни молодые люди отвечали - «mухум - это то, чем можно гордиться». Других функций, помимо символических, у него не остается.

Существенно меняется модель брачных отношений. Организация брака родителями практически без ведома молодых, и, возможно, против их воли уходит в прошлое. В случае принуждения к браку молодой человек может, уехав на другую территорию, завести вторую семью и вообще перестать заботиться о первой. Ослабляется, а во многих случаях и вообее сходит на нет роль принадлежности к тому или иному роду при организации брака. Это может иметь значение в первую очередь в том случае, когда между родами есть старая вражда. Материальное положение и карьерные перспективы будущего жениха играют более значимую роль. В знакомстве молодых людей все большее место занимают социальные сети. В Дагестане фундаменталистский ислам выступил серьезным фактором слома традиции эндогамных браков - выбор пары на основе общности религиозной идеологии, а не родственных либо соседских связей, в том числе против воли родителей, характерен, например, для исламского сообщества Махачкалы.

В то же время нельзя сказать, что на смену традиционной модели брака пришла альтернативная модель, основанная на самостоятельном поиске пары. Молодые люди (в первую очередь юноши) оказываются не готовыми брать на себя ответственность за создание семьи, вынуждая родителей вмешиваться в этот процесс даже тогда, когда сами родители этого не желают. Ожидания молодых супругов от брака часто резко разнятся, приводя к многочисленным разводам. Трансформация гендерных ролей вызывает новые напряжения - образованная, ориентированная на карьеру женщина предъявляет другие требования к спутнику жизни. В некоторых сообществах девушку стремятся выдать замуж как можно раньше, пока не появились завышенные требования, в других же брачный возраст существенно растет. В отдельных республиках, где традиционные модели семьи сильны, одной из стратегий городских образованных девушек становится максимальное 
оттягивание замужества, а иногда и отказ от него в пользу карьеры, для которой традиционная семья возможностей не предоставляет.

В этих условиях некоторые неоднозначные процессы в сфере взаимоотношений между полами могут иметь совершенно разное содержание в зависимости от контекста, в котором они происходят. Так, ритуал похищения невесты, если он случается против ее воли, является насилием над женщиной; если же он совершается по предварительной договоренности - это способ избежать свадебных расходов или последствий родовой вражды и, соответственно, механизм либерализации гендерных отношений. Кроме того, ранние браки и многоженство могут быть проявлением архаичных форм гендерных взаимоотношений, а могут выступать специфической местной формой сексуальной революции, когда, например, родители вынуждены соглашаться на ранний брак детей, опасаясь, что в противном случае между ними возникнут внебрачные сексуальные отношения.

В то же время снижение потенциальной поддержки со стороны рода и реальность развода повышают важность создания женщине возможностей самостоятельно обеспечить себя. Поэтому родители все чаще осознают необходимость дать образование дочерям: «Вдруг не сложилось, вдруг что-то - осталась одна с ребенком. Куда без образования, куда без работы? Последние годы все хотят, чтобы дочери имели образование не хуже, чем сыновья» (жен., сред. возраст, КБР). Меняются и подходы к воспитанию детей. Все меньше используются жесткие физические наказания - «лучше поговорить». Растет роль отца в воспитании детей, традиционная отстраненность сменяется вовлеченностью:

Я не хочу сказать, что отец меня обижал. Ему некогда было со мной заниматься. $<\ldots>$ Я со своими детьми - я ... одноклассник, я ... друг, я и отец, где нужно, и мать. Но они знают эту рамку, они не выходят... вот эту связь я держу потому, что так вижу. < .. > Их нельзя унижать. Их, если нужно, надо наказать. Они должны знать - за что. Их надо хвалить, когда нужно. Не все время - когда нужно (муж., сред. возраст, Дагестан).

На основании собранных интервью создается также впечатление, что в исламских семьях преодолевается отношение к девочкам как к детям «второго сорта», которое было характерно для традиционных семей (Смирнова 1983; Карпов 2013) и оказывало негативное влияние на их социализацию.

Сохраняется обязанность детей заботиться о родителях в старости, жить с ними и помогать им по хозяйству. Но если раньше эта обязанность лежала на младшем сыне, сейчас возможны вариации - если младший сын хорошо устроен и живет далеко от дома, с родителями может остаться кто-то другой из детей.

Рассматриваемые изменения не являются универсальными и единообразными. В ряде случаев они происходят медленно и фрагментарно. Можно найти семьи и сообщества, где все осталось по-старому. И тем 
не менее эрозия традиционной кавказской модели семьи налицо. Но можно ли каким-то образом измерить, насколько широкое распространение получила анализируемая трансформация и как ее интенсивность различается в территориальном разрезе?

\section{Характеристика трансформации традиционных семейных отношений: результаты количественного исследования}

В 2016 г. проведено исследование о ценностях дагестанских мусульман, в 2017 г. аналогичное исследование реализовано среди чеченцев и ингушей. Оба проведены в форме интернет-опроса. Основная задача, которая при этом ставилась - не обеспечить репрезентативность по населению соответствующих республик в целом, а отразить взгляды различных групп мусульман: «этнических» (чувствующих себя мусульманами, но не придерживающихся исламских норм) и практикующих (выполняющих свойственные исламу ритуалы и требования). В частности, важно исследовать ценности той группы, которую называют «нетрадиционными мусульманами», салафитами или фундаменталистами, и которые выступают за очищение исламских норм от позднейших наслоений и максимальное их внедрение в повседневную жизнь. Наряду с обычными вопросами, в анкете использовались виньетки - особого типа вопросы, в которых респондентам описывается некоторая ситуация и предлагается определить свое отношение к ней, дать совет ее участникам или предположить, как они вели бы себя в таких обстоятельствах. Включение виньеток позволяет выявить те ценности, на которые респонденты опираются в повседневной жизни и которые могут отличаться от ценностных деклараций.

По дагестанскому опросу в анализ включено 1675 анкет, по опросу чеченцев и ингушей - 614. Основные социально-демографические показатели выборки по опросу дагестанских мусульман: $70 \%$ мужчин и $30 \%$ женщин; средний возраст респондентов - 40 лет, 73 \% имеют высшее образование, более $70 \%$ - городские жители. Поскольку мужчины и женщины в рамках опроса характеризуются разной степенью религиозности, проведенный ниже гендерный анализ ценностей частично дополнен аналогичным анализом только по практикующим мусульманам. Во втором опросе приняло участие $51 \%$ чеченцев и 49\% ингушей, $69 \%$ из них городские жители, $80 \%$ имеют высшее образование, соотношение мужчин и женщин $55 / 45 \%$, средний возраст - 37 лет. Результаты анализировались дескриптивными методами, путем сопоставления долей респондентов, давших тот или иной ответ на вопрос анкеты, среди разных подгрупп опрошенных (по национальной или религиозной самоидентификации).

Семья как для дагестанцев, так и для чеченцев и ингушей является чрезвычайно важной ценностью - на это указали почти все принявшие участие в опросе. И те, и другие в первую очередь стремятся воспитать 
в детях трудолюбие, ответственность, терпимость и уважение к другим людям, а также религиозность. Послушание явно не относится к приоритетам, при этом для чеченцев и ингушей оно важнее, чем для дагестанцев. Решительность и независимость несколько более важны, чем послушание, но занимают не первые места в перечне необходимых качеств.

Для оценки состояния поколенческих иерархий респондентам предложена следующая ситуация (виньетка): «Представьте, что вы выходите во двор и видите такую картину - пожилой человек громко ругается матом на детей, играющих на детской площадке. Как бы вы поступили в этой ситуации?» Среди дагестанцев готовы сделать замечание старику $73 \%$, среди чеченцев и ингушей лишь 55 \%. Среди молодежи до 35 лет и женщин эта доля ниже, 64 и $66 \%$ по дагестанцам, 44 и 39\% по чеченцам и ингушам. Однако у религиозной молодежи Дагестана она существенно выше, чем среди нерелигиозной - 65 против $57 \%$ считают, что неправильно указывать старшим, $7 \%$ дагестанцев и $22 \%$ чеченцев и ингушей, причем среди женщин в последней группе эта доля повышается до $31 \%$.

Косвенно поколенческие отношения измерялись другой виньеткой, где респондентам была предложена ситуация выбора имама в селе. Выбирать нужно было между молодым человеком с хорошим зарубежным религиозным образованием и пожилым, не имеющим серьезного исламского образования. Однако здесь, очевидно, к поколенческим факторам примешивались и другие - оценка важности обучения, боязнь радикализма со стороны молодого имама. Кроме того, значительная часть респондентов - более $40 \%$ - сочли, что представленной информации недостаточно для принятия решения, либо затруднились ответить. Среди дагестанцев «победил» старый имам, среди чеченцев и ингушей - молодой. Более склонны голосовать за молодого кандидата респонденты до 35 лет, в первую очередь религиозные, а также представители «нетрадиционного» ислама. Таким образом, результаты количественного исследования в целом подтвердили выводы качественного анализа о том, что поколенческие иерархии ослабевают, при этом в разных республиках различными темпами, и ислам, особенно нетрадиционный, служит инструментом разрушения традиционных поколенческих отношений.

Хотя предложенные виньетки не описывают семейные отношения, сделанные на их основе выводы не могут не иметь отношения и к трансформации семейных традиций. Для характеристики гендерных отношений в опрос включен блок вопросов и виньеток, которые касались в первую очередь допустимости трудовой дискриминации женщин и семейного насилия. Виньетки были связаны с выбором образовательных стратегий для детей различного пола, брачной стратегии для девушки и того, на каких условиях муж может разрешить работать жене при наличии двух маленьких детей (табл. 1). Анализ позволил выделить три тенденции, характеризующие ситуацию в данной сфере. 
Результаты количественного исследования ценностей по гендерным вопросам

Опрос дагестанцев (\%)

Опрос чеченцев и ингушей (\%)

\begin{tabular}{|c|c|c|c|c|c|c|c|}
\hline \multirow{2}{*}{ Bonpoc } & \multirow{2}{*}{$\begin{array}{c}\text { Вариант(ы) } \\
\text { ответов }\end{array}$} & \multicolumn{2}{|c|}{ Всего } & \multicolumn{2}{|c|}{ до 35 лет } & \multicolumn{2}{|c|}{ женццинь } \\
\hline & & & & & & & \\
\hline $\begin{array}{l}\text { Заслуживает ли оправдания, } \\
\text { если муж бьет жену }\end{array}$ & $\begin{array}{l}\text { Никогда } \\
\text { не оправдано }\end{array}$ & 58 & 61 & 55 & 64 & 79 & 71 \\
\hline $\begin{array}{l}\text { Заслуживает ли оправдания, } \\
\text { если родители бьют детей }\end{array}$ & $\begin{array}{l}\text { Никогда } \\
\text { не оправдано }\end{array}$ & 28 & 32 & 23 & 29 & 40 & 38 \\
\hline $\begin{array}{l}\text { Насколько вы согласны с тем, } \\
\text { что когда рабочих мест мало, } \\
\text { у мужчин должно быть больше } \\
\text { прав на работу, чем у женщин }\end{array}$ & $\begin{array}{l}\text { Полностью или } \\
\text { скорее согласен }\end{array}$ & 56 & 58 & 68 & 60 & 37 & 47 \\
\hline $\begin{array}{l}\text { Насколько вы согласны с тем, } \\
\text { что если женщина зарабатыва- } \\
\text { ет больше, чем ее муж, это } \\
\text { почти наверняка вызовет } \\
\text { проблемы }\end{array}$ & $\begin{array}{l}\text { Полностью или } \\
\text { скорее согласен }\end{array}$ & 52 & 47 & 53 & 42 & 40 & 40 \\
\hline \multirow{3}{*}{$\begin{array}{l}\text { У Мусы двое детей - дочь } \\
\text { Амина } 17 \text { лет и сын Магомед } \\
16 \text { лет. Амина отличница, } \\
\text { а Магомед с трудом учится } \\
\text { на тройки. У Мусы есть } \\
\text { деньги, чтобы отправить } \\
\text { учиться в университет только } \\
\text { одного ребенка. Как вы } \\
\text { думаете, как должен посту- } \\
\text { пить Муса? }\end{array}$} & $\begin{array}{l}\text { Отправить } \\
\text { учиться дочь }\end{array}$ & 59 & 52 & 49 & 46 & 75 & 64 \\
\hline & $\begin{array}{l}\text { Отправить } \\
\text { учиться сына }\end{array}$ & 21 & 28 & 26 & 31 & 12 & 21 \\
\hline & $\begin{array}{l}\text { Не отправлять } \\
\text { ни дочь, ни сына, } \\
\text { потратить деньги } \\
\text { на хозяйство }\end{array}$ & 8 & 7 & 10 & 7 & 3 & 3 \\
\hline \multirow{3}{*}{$\begin{array}{l}\text { Магомедрасул (Мурат*) } \\
\text { размышляет над будущем } \\
\text { своей дочери Хадижат } \\
\text { (Хадиджи*), которая на отлич- } \\
\text { но заканчивает школу. Деньги, } \\
\text { чтобы отправить ее учиться } \\
\text { в Москву или в республикан- } \\
\text { скую столицу, есть. Как } \\
\text { следует поступить Магомедра- } \\
\text { сулу (Мурату)? }\end{array}$} & $\begin{array}{l}\text { Отправить дочь } \\
\text { в Москву } \\
\text { на медицинский. } \\
\text { Там она сможет } \\
\text { стать хорошим } \\
\text { специалистом }\end{array}$ & 28 & 22 & 25 & 17 & 33 & 24 \\
\hline & $\begin{array}{l}\text { Оправить дочь } \\
\text { на престижный } \\
\text { факультет } \\
\text { республиканского } \\
\text { ВУЗа }\end{array}$ & 4 & 28 & 5 & 32 & 3 & 18 \\
\hline & $\begin{array}{l}\text { Выдать дочь } \\
\text { замуж и не от- } \\
\text { правлять учиться }\end{array}$ & 19 & 8 & 27 & 9 & 2 & 3 \\
\hline
\end{tabular}




\begin{tabular}{|c|c|c|c|c|c|c|c|}
\hline \multirow{2}{*}{ Bonpoc } & \multirow{2}{*}{$\begin{array}{c}\text { Вариант(ы) } \\
\text { ответов }\end{array}$} & \multicolumn{2}{|c|}{ Всего } & \multicolumn{2}{|c|}{ до 35 лет } & \multicolumn{2}{|c|}{ женецины } \\
\hline & & & & - & & & \\
\hline $\begin{array}{l}\text { Магомедрасул (Мурат*) } \\
\text { размышляет над будущем } \\
\text { своей дочери... }\end{array}$ & $\begin{array}{l}\text { Это дело дочери. } \\
\text { Пусть решает сама }\end{array}$ & 40 & 38 & 33 & 38 & 57 & 53 \\
\hline
\end{tabular}

Марьям (Лейла*) закончила медицинский институт и хочет устроиться на работу в госпиталь. У Марьям (Лейлы) двое детей - 5-ти и 4-х лет. Как вы считаете, как должен повести себя в этой ситуации муж Марьям (Лейлы)?
Не разрешать ни при каких

$\begin{array}{lllllll}\text { условиях } & 3 & 4 & 5 & 5 & 1 & 1\end{array}$

Не разрешать, пока дети

\begin{tabular}{|c|}
\hline не пойдут в школу \\
\hline
\end{tabular}

Разрешить только

в женский

коллектив

$\begin{array}{llllll}15 & 12 & 23 & 14 & 4 & 7\end{array}$

Разрешить без

$\begin{array}{lllllll}\text { всяких условий } & 16 & 16 & 9 & 14 & 27 & 25\end{array}$

Разрешить если

родители

согласны смотреть

за внуками

$\begin{array}{llllll}7 & 6 & 6 & 4 & 7 & 7\end{array}$

Разрешить если есть возможность устроить детей в детский сад

$\begin{array}{llllll}51 & 55 & 49 & 55 & 58 & 57\end{array}$

Насима (Джамиля*) хочет создать семью и иметь детей, но никак не может выйти замуж. Что бы вы посоветовали Насиме (Джамиле)?

$\begin{array}{llllll}8 & 7 & 6 & 7 & 8 & 9\end{array}$

Активно искать мужа самостоятельно

Активно просить родственников посватать ее 20

Особенно

не проявлять

активность - все

равно все

сложится как

сложится

$\begin{array}{lllll}53 & 59 & 50 & 60 & 68\end{array}$

67

\footnotetext{
* В опросе чеченцев и ингушей в отдельных вопросах использовались имена, отличные от дагестанских.
}

Первая тенденция связана с усилением консерватизма в гендерных отношениях и роли ислама в данном консервативном повороте. Наиболее 
полно она нашла свое проявление среди дагестанцев. Здесь практически по всем перечисленным сюжетам позиция молодежи и позиция представителей нетрадиционного ислама более консервативна, чем в целом по выборке. Эти группы в большей мере оправдывают семейное насилие, как по отношению к жене, так и детям, а также дискриминацию женщин в трудовой сфере, меньше готовы отправить дочь-отличницу получать хорошее образование и чаще предпочитают вместо этого выдать ее замуж, менее настроены на то, чтобы позволить жене выйти на работу, даже если удастся обеспечить уход за детьми, и больше - на то, чтобы разрешить работать только в женском коллективе.

Среди чеченцев и ингушей ситуация не столь однозначна. Так, молодежь в меньшей мере готова оправдать насилие в отношении жены, чем представители более старших возрастов: $64 \%$ среди молодых и лишь $54 \%$ респондентов старшего возраста считают, что, если муж бьет жену, это никогда не оправдано. Салафиты решительно отрицают насилие в отношении детей, по сравнению с другими религиозными группами и чем в среднем по выборке. Молодежь в большей мере, чем среднее поколение, готово предоставить право дочери самой решать свою судьбу. Не сильно отличается от средней (причем в разные стороны) поддержка трудовой дискриминации женщин среди молодежи и представителей «нетрадиционного» ислама. В то же время больший консерватизм этих групп в отношении работы жены и учебы дочери нашел отражение в результатах опроса.

Однако есть сфера, где консервативный гендерный поворот явно не проявился, более того, выявилась некоторая тенденция в противоположном направлении. Это касается активности женщины в поиске супруга: $53 \%$ дагестанцев и $59 \%$ чеченцев и ингушей считают, что особой активности в этом вопросе девушке проявлять не нужно - все равно все сложится, как сложится. Сами женщины в еще большей мере поддерживают эту позицию - $68 \%$ дагестанок и $67 \%$ чеченок и ингушек. Лишь $28 \%$ респондентов-дагестанцев и $27 \%$ чеченцев и ингушей признают возможность для девушки самостоятельно искать мужа или активно просить родственников ее посватать (причем предпочтение явно отдается второму варианту). У последних особых различий между религиозными и возрастными группами не наблюдается. А вот среди дагестанских респондентов ситуация иная - возможность активности девушки в данном вопросе признают 33 \% до 35 лет и 38 \% представителей «нетрадиционного» ислама (то есть среди них доля признающих такую возможность больше, чем в целом по выборке дагестанцев).

Вторая тенденция связана с тем, что консерватизм в гендерном вопросе в декларативных утверждениях проявляется больше, чем при принятии конкретных решений. Так, полностью либо скорее согласен с тем, что, когда рабочих мест мало, у мужчин больше прав на работу, 51 \% дагестанцев (в возрасте до 35 лет - 68\%) и 58\% чеченцев и ингушей (в возрасте до 35 
лет $-60 \%$ ). В то же время отправить учиться не сына-троечника, а дочьотличницу (что потенциально может усилить конкуренцию женщин за рабочие места) готовы 59\% дагестанцев (в том числе 49\% до 35 лет) и $52 \%$ чеченцев и ингушей (46\% до 35 лет).

Третья тенденция отражает значительный разрыв в позициях мужчин и женщин по гендерным вопросам, выявившийся в рамках опроса. В целом различия между мужчинами и женщинами по доле считающих недопустимым семейное насилие составляют от полутора до четырех раз. Судя по всему, среди дагестанцев этот разброс еще больше, чем среди чеченцев и ингушей. Так, семейное насилие в отношении жены считают никогда не оправданным 49\% мужчин среди дагестанцев и 79\% женщин, по чеченцам и ингушам соответствующие ответы составили $53 \%$ среди мужчин на $71 \%$ среди женщин. Аналогичные показатели в отношении допустимости насилия над детьми - 23/40\% и 27/38\%. Интересно, что в Дагестане практикующие мусульманки и молодые женщины в большей мере считают допустимыми физические наказания, чем другие женщины выборки, однако существенная разница с мужчинами соответствующих категорий все равно сохраняется.

Женщины не поддерживают трудовую дискриминацию и дискриминацию дочерей в получении образования. Так, разрешение жене с двумя маленькими детьми выйти на работу без всяких дополнительных условий считают правильным $11 \%$ мужчин и $27 \%$ женщин среди респондентовдагестанцев и, соответственно, $9 \%$ и $25 \%$ среди чеченцев и ингушей. А вот разрешение жене выйти на работу только в женский коллектив готовы поддержать $20 \%$ респондентов-мужчин среди дагестанцев и лишь $4 \%$ женщин, среди практикующих мусульманок эта доля поднимается до $6 \%$. По чеченцам и ингушам соответствующие ответы составляют $15 \%$ у мужчин и $7 \%$ у женщин. При выборе между обучением дочериотличницы и сына-лентяя среди дагестанцев отдать предпочтение дочери считают нужным $52 \%$ респондентов-мужчин и $75 \%$ женщин $(70 \%$ среди практикующих мусульманок), среди чеченцев и ингушей распределение ответов между мужчинами и женщинами $-42 / 64 \%$. И уж совсем негативно женщины относятся к идее не отправлять дочь-отличницу учиться и выдать ее замуж - к такому варианту склоняется лишь 2-3\% женщин, тогда как среди респондентов-мужчин эта доля составляет $12 \%$ у чеченцев и ингушей и $26 \%$ у дагестанцев (у практикующих мусульман - 33 \%).

Таким образом, в гендерных отношениях на Северном Кавказе заложена «бомба замедленного действия» - консервативный поворот является в первую очередь мужским феноменом, в то время как среди женщин, в том числе практикующих мусульманок, наблюдается явный запрос на эмансипацию. Причем анализ, проведенный в рамках дагестанского опроса, демонстрирует, что разрыв между позициями женщин и мужчин по гендерным вопросам в целом нарастает - у молодых он больше, чем 
среди пожилых, хотя по многим вопросам параллельно усиливается и консервативность позиций женщин. Усиление разрыва не наблюдается в декларациях о трудовой дискриминации и лишь намечается в проблемах семейного насилия. Но при анализе конкретных ситуаций, связанных с возможностью жены работать или с обучением дочерей, этот фактор заявляет о себе в полную силу. Так, мнения мужчин и женщин старшего поколения по вопросу о возможности работы жены с маленькими детьми без дополнительных условий либо при возможности обеспечить уход за детьми практически совпадают, тогда как среди молодых женщин и мужчин позиции расходятся в 1,6 раза. Примерно такое же соотношение $(1,5: 1)$ складывается по вопросу о том, чтобы отправить дочь-отличницу учиться в Москву. По вопросу об ограничении возможности жены работать только женским коллективом среди старших позиции различаются в два раза, среди молодых - в четыре. Учебу дочери-отличницы, а не сына-лентяя среди старших поддерживает в 1,2 раза больше женщин, чем мужчин, среди молодых - в 1,7 раза. Разрыв позиций по вопросу о самостоятельном выборе дочерью своего будущего составляет 1,3 в старшем поколении и два - в молодом. Таким образом, можно предположить, что проблема нарастает и, вполне возможно, будет нарастать и далее.

\section{Заключение}

Представления о традиционности модели семьи в северокавказском регионе приводят к предложениям регулировать поведение молодого поколения на основе авторитета старших, предотвращать с опорой на старшее поколение различные эксцессы, например, при обучении молодежи в других регионах. Между тем необходимо понимать, что традиционные механизмы внешнего контроля и регулирования поведения возможны только в замкнутых общностях. В этих условиях попытки перенесения подобных механизмов на ситуацию больших городов вдали от дома неизбежно оборачиваются опорой не на авторитет старших, а на явное или неявное насилие, нарушающее законодательно закрепленные права граждан РФ.

Безосновательно пытаться возлагать ответственность на семью и род за то, что молодые люди становятся приверженцами радикального ислама. Радикальные исламские взгляды в наибольшей мере отрицают значение семьи и авторитет старших. Эволюция молодых людей происходит в первую очередь в сообществах сверстников и единомышленников, их вхождение в радикальные исламские группы во многих случаях становится для членов семьи полной неожиданностью. При этом необходимо учитывать, что традиционная семья не приспособлена к тому, чтобы отслеживать эволюцию личности молодого человека. Здесь важна не индивидуальность, а внешние проявления - пока молодой человек не нарушает сложившихся норм, оснований для беспокойства в рамках подобной системы не наблюдается. 
Особого осмысления требует очевидный ценностный разрыв между мужчинами и женщинами по гендерным вопросам. Для борьбы с консервативным поворотом необходимо создавать дополнительные условия для того, чтобы женщины могли публично высказывать свою точку зрения и в большей мере влиять на решения, принимаемые в данной сфере.

\section{Выражение признательности}

Статья отражает результаты исследования автора в рамках НИР РАНХиГС 2018 г. «Влияние социокультурных факторов на результаты политики поддержки рождаемости в Российской Федерации». Количественное полевое исследование проводилось исследовательской группой в составе И. Стародубровской, Е. Варшавера, Е. Лазарева. Автор благодарит Е. Варшавера за помощь в обработке статистического материала и проведении анализа.

\section{Список источников}

Карпов Ю.Ю. (2013) Женское пространство в культуре народов Кавказа. Нальчик: Полиграфсервис и Т.

Кисриев Э. Ф. (2004) Ислам и власть в Дагестане. М.: ОГИ.

Павлова О.С. (2013) Чеченский этнос сегодня: черты сочиально-психологического nортрета. М.: Сам Полиграфист.

Сабанчиева Л.Х. (2016) Гендер в сочиально-политических прочессах в КабардиноБалкарии (20-е гz. XX в.- начало XXI в.). Нальчик: КБИГИ.

Смирнова Я.С. (1983) Семья и семейный быт народов Северного Кавказа (вторая половина $X I X-X X$ в.). М.: Наука.

Стародубровская И. В., Соколов Д. В. (2013) Истоки конфликтов на Северном Кавказе. М.: Дело, РАНХиГС.

Теннис Ф. (2002) Общность и общество: Основные понятия чистой социологии. СПб.: Владимир Даль.

Lewis O. (1973) Some Perspectives on Urbanization with Special Reference to Mexico City. A. Southall (ed.) Urban Antropology. Cross-Cultural Studies of Urbanization. New York: Oxford University Press: 125-138.

Molodikova I., Watt A. (2014) Growing Up in the North Caucasus. Society, family, religion and education. London: Routledge.

Tipps D. (1973) Modernization Theory and the Comparative Study of Societies: A critical perspective. Comparative Studies of Society and History, 15 (2): 199-226. 
Irina Starodubrovskaya

\section{THE CRISIS OF THE TRADITIONAL NORTH CAUCASIAN FAMILY IN THE POST-SOVIET PERIOD AND ITS CONSEQUENCES}

The North Caucasus is often treated as a region where family traditionalism has been very well preserved until the present day, something seen in strong gender asymmetries, the high authority of elder people within families, and widespread acceptance of family violence. However, this research shows that the traditional model of the North Caucasus family at present is in crisis. This thesis emerges from an analysis of both qualitative and quantitative data. Evidence taken from qualitative fieldwork in several regions of the North Caucasus in 2014-2018 highlight the possible reasons behind and consequences of this weakening of generation and gender hierarchies within a family, which brings with it the liberation of nuclear families from kinship and local community pressure. A quantitative online survey conducted in 2017 confirmed the weakening of generational hierarchies and the role of radical Islam in this process, but at the same time demonstrated that a conservative turn has occurred with regard to gender issues. This turn is accompanied by an increasing gap in the gender values of men and women which can form the basis for the future crisis in this area (that gap was of different size in different regions of the North Caucasus). It is found that non-traditional Islam has a strong impact on family practices, which is rather contradictory as it on the one hand strengthens gender asymmetries while, on the other, emphasizes personal responsibility instead of family duties. The social consequences of this crisis in the traditional family are mainly related to the inability of elders to control the younger generations and the inefficiency of their appeals to authority in situations where North Caucasus youth behave inappropriately in other Russian regions or come under the influence of Islamic radicalization. Finally, the failings of a youth policy based on the assumption of unbreakable family traditionalism in the North Caucasus is also discussed.

Key words: traditional family, generation and gender hierarchies, marriage strategies, conservative gender values, Islam

DOI: 10.17323/727-0634-2019-17-1-39-56

\section{References}

Karpov Yu.Yu. (2013) Zhenskoye prostranstvo v culture narodov Kavkaza [Women's Space in the Culture of the Caucasus peoples]. Nalchik: Poligrafservis i T.

Irina V. Starodubrovskaya - PhD (kandidat nauk) in Economics, head of the research group 'Political Economy and Regional Development' at the Gaidar Institute for Economic Policy, Moscow, Russian Federation. Email: irinavstar@gmail.com 
Kisriev E. F. (2004) Islam i vlast'v Dagestane [Islam and Power in Daghestan]. Moscow: O.G.I.

Lewis O. (1973) Some Perspectives on Urbanization with Special Reference to Mexico City. In: A. Southall (ed.) Urban Anthropology. Cross-Cultural Studies of Urbanization. New York: Oxford University Press: 125-138.

Molodikova I., Watt A. (2014) Growing Up in the North Caucasus. Society, Family, Religion and Education. London: Routledge.

Pavlova O. S. (2013) Chechenskiy etnos segodnya: cherty sotsialno-psikhologicheskogo portreta [Chechen Ethnic Group: Features of the Socio-Psychological Portrait]. Moscow: Sam Poligraphist.

Sabanchieva L.H. (2016) Gender v sotsialno-politicheskikh protsessakh v Kabardino-Balkarii (20-ye godi XX veka - nachalo XXI veka) [Gender in Socio-Political Processes in KabardinoBalkaria $\left(1920^{\text {th }}-\right.$ the Beginning of $21^{\text {st }}$ Century)]. Nalchik: KBIGI.

Smirnova Ja. S. (1983) Semja I semejnyj byt narodov Severnogo Kavkaza (vtoraja polovina $X I X-\$ 5 X$ vek [Family and Household of the Peoples of the North Caucasus (Second Half of the $19^{\text {th }}-20^{\text {th }}$ Centuries]. Moscow: Nauka.

Starodubrovskaja I. V., Sokolov D. V. (2013) Istoki konfliktov na Severnom Kavkaze [Sources of Conflicts in the North Caucasus]. Moscow: Delo, RANEPA.

Tipps D. (1973) Modernization Theory and the Comparative Study of Societies: A critical perspective. Comparative Studies of Society and History, 15 (2): 199-226.

Tönnies F. (2002) Obshchnost' i obshchestvo: Osnovnye ponyatiya v sotsiologii [Gemeinschaft und Gesellschaft: Grundbegriffe der reinen Sociologie]. St. Petersburg: Vladimir Dal'. 